\title{
Perceptions of Judicial Independence in European Countries
}

\begin{abstract}
The perceptions of judicial independence of judges, lawyers, general public and companies are analysed across countries. The perceptions of these categories are strongly correlated. However, the mean scores differ: judges are much more positive about their independence than lawyers, and lawyers are much more positive than the general public and companies. As to the general public, highly educated citizens are generally more positive about the presence of independence than citizens with lower education levels. The difference increases with the degree of independence. Citizens with little education in very different countries have similar perceptions of judicial independence. The limited information that is available about court users suggests that persons with recent experience with the courts are less positive about independence than persons without experience. For companies the reverse is apparent. Among both the general public and companies, the perceptions diverge more with experience than without experience, likely as a result of winning or losing a case.
\end{abstract}

Keywords Judicial independence · Survey · Judges · Lawyers · Citizens · Court users 


\subsection{Surveys About Independence}

Several surveys about judicial independence are available for countries of Europe. Table 3.1 provides an overview. These surveys allow a comparison of the perceptions of citizens and companies in general with the perceptions of lawyers and judges. In this Chapter these perceptions are compared and analysed. Since 2016 surveys are conducted at the request of the European Commission annually about the perceptions of judicial independence among the general public and among companies. The European Network of Councils for the Judiciary (ENCJ) has held by now three surveys among the judges of Europe about their independence. The latest survey was conducted in February/March 2019. The surveys

Table 3.1 Surveys on judicial independence by category of respondents

\begin{tabular}{|c|c|c|c|c|}
\hline & $\begin{array}{l}\text { Number of } \\
\text { respondents }\end{array}$ & Country coverage & $\begin{array}{l}\text { Period of } \\
\text { collection }\end{array}$ & $\begin{array}{l}\text { Terminology in } \\
\text { relevant } \\
\text { question }\end{array}$ \\
\hline General public & 26,446 & 28 EU-members & $\begin{array}{l}\text { January } \\
2019\end{array}$ & $\begin{array}{l}\text { Courts and } \\
\text { judges }\end{array}$ \\
\hline Companies & 6,808 & 28 EU-members & $\begin{array}{l}\text { January } \\
2019\end{array}$ & $\begin{array}{l}\text { Courts and } \\
\text { judges }\end{array}$ \\
\hline \multirow[t]{2}{*}{$\begin{array}{l}\text { Court users } \\
\text { (parties) }\end{array}$} & $\begin{array}{l}1,573 \\
\text { (citizens) } \\
734 \\
\text { (companies) }\end{array}$ & $\begin{array}{l}\text { As the above } \\
\text { surveys }\end{array}$ & $\begin{array}{l}\text { January } \\
2019\end{array}$ & $\begin{array}{l}\text { Courts and } \\
\text { judges }\end{array}$ \\
\hline & Varied & $\begin{array}{l}\text { Some national } \\
\text { surveys }\end{array}$ & Misc. & Judge \\
\hline Lawyers & 4,489 & $\begin{array}{l}21 \text { Countries with } \\
\text { sufficient response }\end{array}$ & 1 Qtr 2019 & Judge \\
\hline Judges & 11,335 & $\begin{array}{l}27 \text { ENCJ members } \\
\text { and observers, incl. } \\
\text { Norway, from } 25 \\
\text { countries }\end{array}$ & 1 Qtr 2019 & Judge \\
\hline Lay judges & 20,605 & $\begin{array}{l}10 \text { ENCJ members } \\
\text { and observers }\end{array}$ & 1 Qtr 2018 & Judge \\
\hline
\end{tabular}

Note The UK participated in all surveys, and is included in the comparisons Sources

General public: Flash Eurobarometer 474 (EC 2019b)

Companies: Flash Eurobarometer 475 (EC 2019a)

Parties: Flash Eurobarometer 474 and 475 and miscellaneous national surveys

Lawyers: ENCJ and CCBE (2019)

Judges: ENCJ (2019)

Lay judges: ENCJ (2018) 
are aimed at professional judges. A separate survey has been carried out by the ENCJ among lay judges in 2018. The opinions of lay judges are the subject of the next Chapter. As to the perceptions of lawyers, at the initiative of the ENCJ the Council of Bars and Law Societies of Europe (CCBE) has recently organized - in parallel with the latest judges survey-a survey among lawyers in 2019. The participation of lawyers in the survey was relatively low and for some countries too low to be informative, despite the efforts of national bar associations. Given the crucial role of lawyers in judicial procedures, this is unfortunate, but together with the other data sources a consistent picture can be constructed.

Then, there are the court users for whom the judicial system exists, but who are difficult to reach. Some information about their perceptions can be derived from the surveys mentioned above at the request of the EC among citizens and companies, as these contain a question about their recent involvement in a dispute that went to court. However, people do not go to court often, and the number of respondents per country is small, while EU-wide aggregate data are not very meaningful given the differences among the constituent nations. In addition, only for a few countries relevant data on the perceptions of court users about concepts that are related to independence are available, as part of court user surveys. Court user surveys generally focus on the services provided by the courts at a practical level, and pay attention to issues such as waiting times, but in some surveys court users were asked about impartiality (the Netherlands) and neutrality of the judge (Denmark).

It should be noted that the comparison of the perspectives of the stakeholders in the judiciary can also be done for an individual country. An example is an interesting study regarding Montenegro that distinguishes the same stakeholders as in this Chapter, and involved extensive data collection (World Bank 2018).

Table 3.2 summarizes the key outcomes of the surveys. As the country coverage of the surveys does not fully overlap, a full comparison is possible for 17 countries (left part of the Table). Leaving out the perceptions of lawyers, 22 countries can be compared (right part). In the notes to the Table the countries in the two sets are specified. It should be noted that of the large countries of the EU France and Poland did not participate in the 2019 judges survey of the ENCJ. France, because of administrative reasons, and Poland, because it has been suspended as a member of the ENCJ (2019). Table 3.2 does not include the court users in the sense 

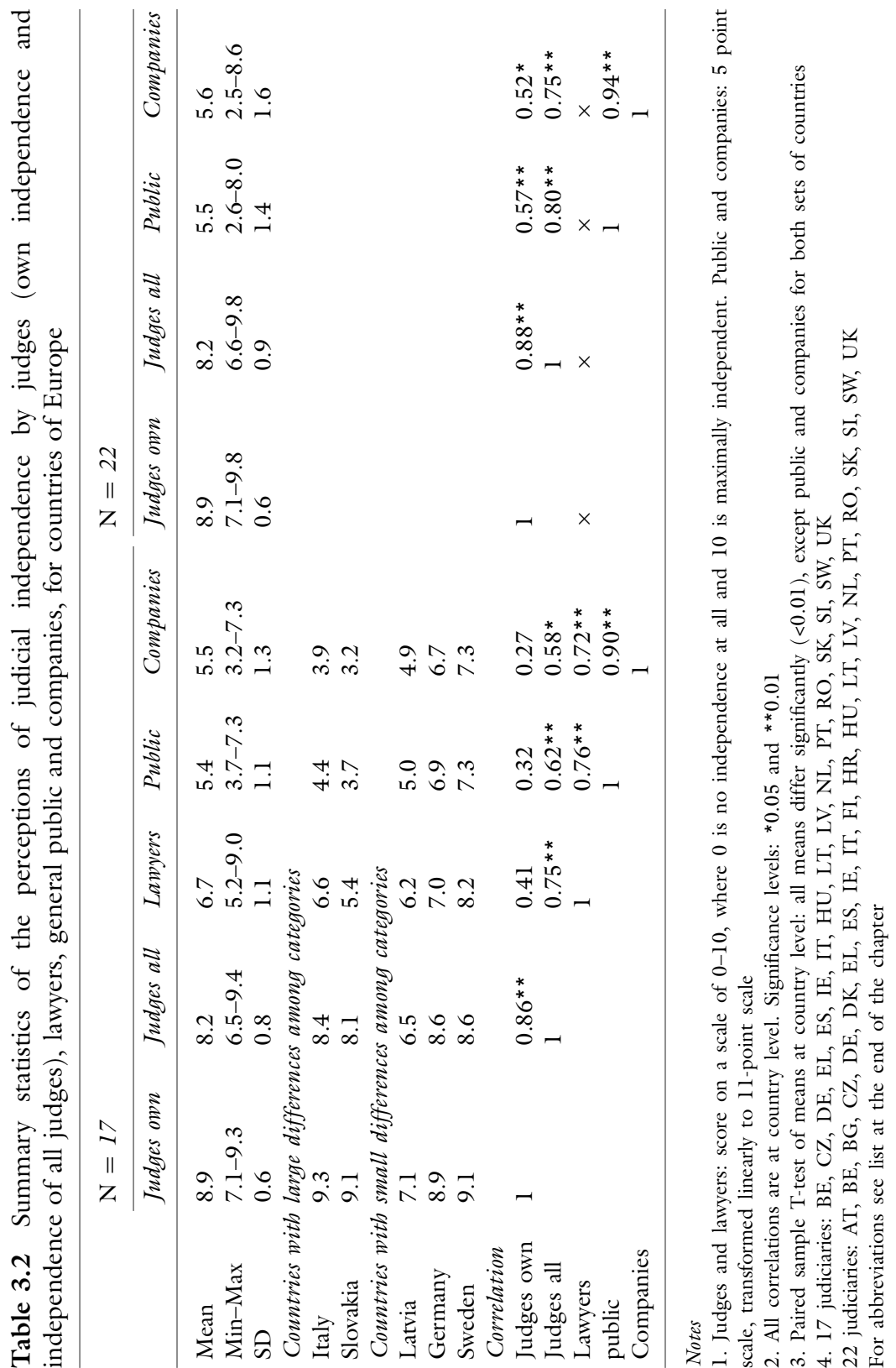
Table 3.3 Summary statistics of the perceptions of judicial independence by judges and lawyers and by citizens and companies with and without experience, for 17 countries of Europe

\begin{tabular}{|c|c|c|c|c|c|c|}
\hline & \multirow{2}{*}{$\begin{array}{l}\text { Judges } \\
\text { all }\end{array}$} & \multirow[t]{2}{*}{ Lawyers } & \multicolumn{2}{|l|}{ Public } & \multicolumn{2}{|l|}{ Companies } \\
\hline & & & Experience & $\begin{array}{l}\text { No } \\
\text { experience }\end{array}$ & Experience & $\begin{array}{l}\text { No } \\
\text { experience }\end{array}$ \\
\hline Mean & 8.2 & 6.7 & 5.0 & 5.5 & 5.7 & 5.4 \\
\hline Min-Max & $6.5-9.4$ & $5.2-9.0$ & $3.5-7.3$ & $3.5-7.3$ & $2.4-8.7$ & $3.2-7.3$ \\
\hline SD & 0.8 & 1.1 & 1.0 & 1.1 & 1.9 & 1.4 \\
\hline \multicolumn{7}{|l|}{ Correlation } \\
\hline Judges all & 1 & $0.75^{\text {** }}$ & $0.54^{*}$ & 0.61 ** & $0.76^{* *}$ & $0.50^{1}$ \\
\hline Lawyers & & 1 & 0.60 ** & $0.76^{* *}$ & 0.77 ** & $0.68 * *$ \\
\hline $\begin{array}{l}\text { Public with } \\
\text { experience }\end{array}$ & & & 1 & 0.79 * * & 0.71 ** & $0.80^{* *}$ \\
\hline $\begin{array}{l}\text { Public no } \\
\text { experience }\end{array}$ & & & & 1 & $0.74^{* *}$ & $0.95^{* *}$ \\
\hline $\begin{array}{l}\text { Companies with } \\
\text { experience }\end{array}$ & & & & & 1 & $0.76^{* *}$ \\
\hline $\begin{array}{l}\text { Companies no } \\
\text { experience }\end{array}$ & & & & & & 1 \\
\hline
\end{tabular}

$1_{p}=0.051$

Note Paired sample $T$-test of means on country level: the means regarding judges and lawyers differ significantly $(<0.01)$ from the means of public and companies. The means regarding the public with and without experience differ significantly $(<0.05)$. The other means regarding companies and between public and companies do not differ significantly $(>0.05)$

of the parties in procedures, because their experience requires a more nuanced description (see Table 3.3). The perceptions of the different actors, starting with the judges, are discussed in the following.

\subsection{Independence as Perceived by Judges}

The judges of Europe are generally positive about their independence. The ENCJ survey asked judges of 27 countries to rate their own independence as well as the independence of the judges in general in their country. ${ }^{l}$ The first question has a personal and narrow scope. The mean score over all 27 judiciaries was 9.0 on an 11-points scale from 0 to 10 .

${ }^{1}$ Literally: "On a scale of 0-10 (where 0 means "not independent at all" and 10 means "highest possible degree of independence") as a judge I am ...". Same, but: "the professional judges in my country are ...". 
$49 \%$ of the respondents gave their independence the maximum score of 10 and $28 \%$ a score of 9.2 Only $4 \%$ gave a score lower than 6 . The question about the independence of the judges in general is less personal as well as potentially broader, as respondents may take aspects such as the selection of judges into account. The mean score was lower, 8.3 with 'only' $24 \%$ of the respondents awarding a score of 10 and $31 \% 9$. Just above $7 \%$ gives a score lower than 6 . Looking at the outcomes per country, the mean scores on own independence range from 7.1 in Latvia to 9.8 in Denmark and on the independence of the judges of the country from 6.5 in Latvia to again 9.8 in Denmark.

The correlation between the scores on the two questions is high. They differ systematically in level, nevertheless. The difference between the mean scores on own independence and on independence of all judges increases with the decrease of the mean score for all judges. ${ }^{3}$ This can be explained partly by the existence of an upper bound which limits the possibilities to score one's own independence when the score for all judges is already close to the ceiling. Another reason might be unwillingness to express lack of independence at the personal level, for instance for fear of negative consequences if the guaranteed anonymity of the survey would be breached. ${ }^{4}$ Still, it seems that it is not beyond judges to be susceptible to illusory superiority (Buunk and Van Yperen 1991), which for instance brings nearly all people to think that they drive their cars better than the median (Svenson 1981), and also offers an explanation why lawsuits go to trial (Landes 1971; Posner 1973). While there are many explanations of this phenomenon, the outcome is likely to be influenced by the context of self with aggregate comparison (Giladi and Klar 2002). Being critical about colleagues may have to do with the actual observation of colleagues in court and their judgments, but also with the appointment and promotion of judges. The ENCJ survey shows that many judges are critical about human resource decisions about judges, and many respond that these decisions are not solely based on merit (see ENCJ 2019, p. 33).

\footnotetext{
${ }^{2}$ Average of countries, to avoid influence of country size.

${ }^{3}$ Linear regression at country level: Ind All $=1.4^{* *} \times$ Ind Own $-4.3^{* *}, N=26$, $R^{2}=0.76$. Thus, if Ind Own $=10$, Ind All $=9.7$, and if Ind Own $=8$, Ind All $=6.9$. Note: excluding Northern Ireland.

${ }^{4}$ Respondents were given a link to the ENCJ website, administered in Brussels.
} 
In view of these explanations, the score for all judges is likely to be a more truthful expression of actual independence than the score for one's own independence. In addition, Table 3.2 shows that the judges' perceptions about judges in general are more strongly correlated with the perceptions of lawyers, citizens and companies than the perceptions of judges about themselves. In the remainder the perceptions about all judges will be used as yardstick for the opinion of judges. It should be stressed that this yardstick concerns the independence of the judiciary, and not the perception of judges of the appearance of independence to the parties and the public. The question of the survey is explicitly phrased in this way.

\subsection{Independence as Perceived by Lawyers}

The survey among lawyers about the independence of the judiciary in their country includes exactly the same question as the survey among the judges about the independence of the judges in general. Lawyers are much more critical about judicial independence than the judges themselves. The mean score over the 17 countries with sufficient response rates is 6.7 with $10 \%$ of the respondents giving a score of 10 and $16 \%$ a score of 9. $31 \%$ allots a score below 6 . At country level, the average score ranges from 5.2 for Hungary to 9.0 for the UK.

The left part of Table 3.2 allows a comparison of lawyers and judges. The perceptions of judges about the independence of the judges in general in their country are highly correlated with the perceptions of the lawyers, while the means differ substantially. This essentially implies that the surveys reveal very similar, consistent differences of perceptions between countries, but they also bring out different views about the level of independence that is achieved.

The mean score by lawyers across countries of 6.7 can be seen as positive, but much less so than the mean score by judges of 8.2. The lower the score given by lawyers, the larger is the difference between the mean score by judges and the mean score by lawyers. ${ }^{5}$ Compare for instance Hungary and Sweden. For Hungary the score of judicial independence by judges is 7.3 and the score by lawyers is 5.2 , resulting in a large difference. For Sweden the scores are 8.6 and 8.2. This phenomenon is similar to that with regard to the two types of perceptions of judges discussed

\footnotetext{
${ }^{5}$ Linear regression at country level: Ind All Judges $=-0.5^{* *} \times$ Ind Lawyers $+4.8^{* *}$, $N=17, R^{2}=0.53$. If Ind Lawyers $=5$, Ind All Judges $=7.3$. If Ind Lawyers $=8$, Ind All Judges $=8.8$.
} 
above. While admittedly lawyers form a critical profession, it is not likely that as a personality trait they are inherently more critical/negative in Hungary than in Sweden. The only exception of the pattern is Latvia. The scores of judges and lawyers are very similar (6.5 vs 6.2$)$. Evaluating the data at individual level for Latvia, reveals that there is no significant difference between judges and lawyers. For each of the other countries the difference is significant. ${ }^{6}$

\subsection{Independence AS PERCeived by the General Public}

Perceptions of the general public are derived from a survey that is fully devoted to the topic of judicial independence. The Eurobarometer phrases the question as follows: "from what you know, how would you rate the justice system in (y)our country in terms of the independence of the courts and judges? Would you say it is very good, fairly good, fairly bad or very bad", allowing also "do not know" as an answer. While the wording and the scale differ, the content is the same as that of the surveys among judges and lawyers. After transformation to an 11-point scale, the mean outcome for all 22 members is 5.5 with a range of 2.6 for Croatia to 8.0 for Denmark. ${ }^{7}$ Table 3.2 gives the scores for the two subsets that are used to compare the categories of actors. Comparing the perceptions of judges (about all judges), lawyers and the public, the mean score drops from 8.2 to 6.7 and to 5.4: lawyers are more critical about judicial independence than judges, and the general public is more critical than the lawyers. For some countries this pattern does not affect the (positive) perception of independence qualitatively (see Fig. 3.1). In these countries all categories of actors are positive about the state of independence (score $>5$ ), albeit to a larger or smaller degree. This is the case for instance for the Netherlands, Sweden and the UK. For other countries the outcomes diverge. For instance, in Spain the score by the judges is 7.8, by lawyers 6.2 and by the public 4.2. This pattern is also found in Slovenia and Italy. This puts in doubt the state of independence in these countries:

\footnotetext{
${ }^{6}$ T-test. Significance level: $0.1 \%$ for all countries except Sweden (1\%) and UK (5\%). For Latvia $p=0.18$.

${ }^{7}$ A simple linear transformation was used to transform the five points scale of the EU barometers as follows: very good: 10, fairly good: 7.5 , don't know: 5 , fairly bad: 2.5 and very bad: 0 . Alternative transformations do not alter the outcomes qualitatively.
} 


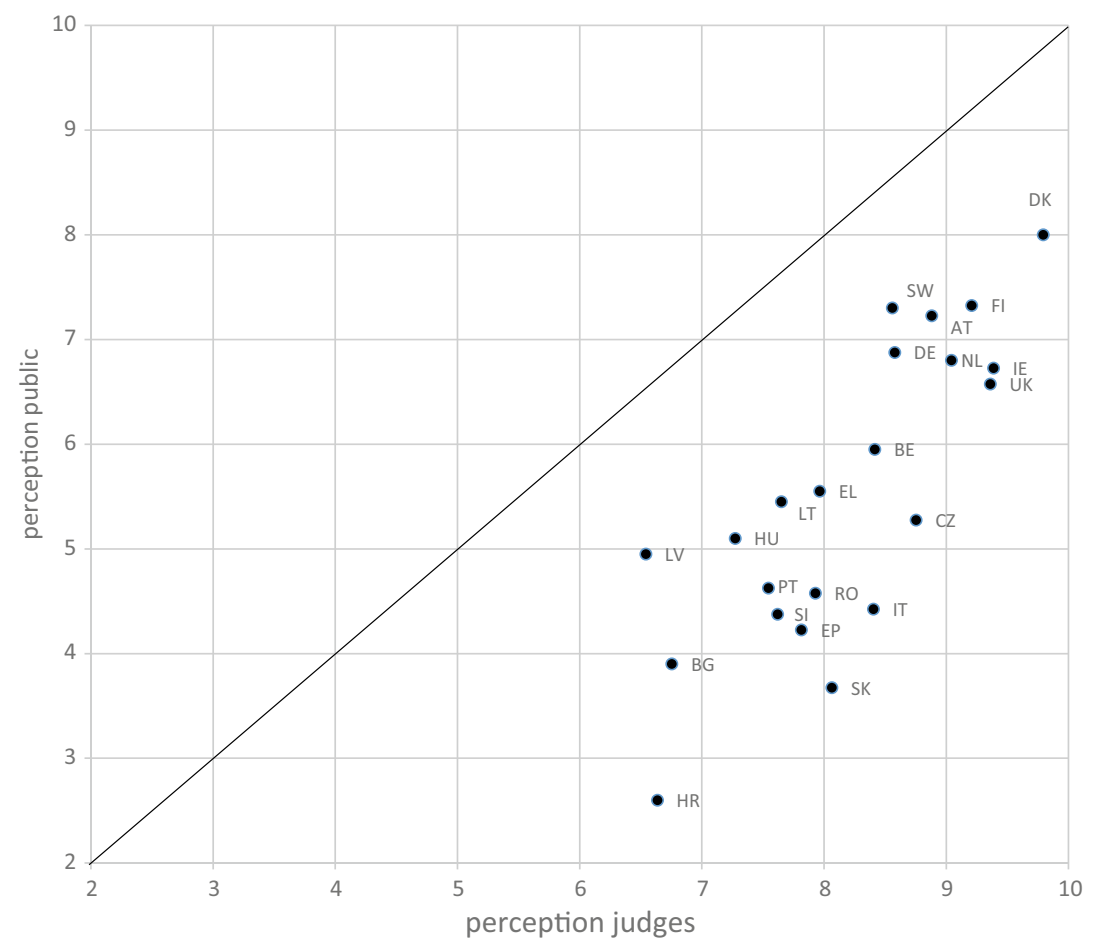

Fig. 3.1 Perceived judicial independence by public and judges, average per country (Note See list of country abbreviations at end of this chapter)

is independence "strong" or "weak"? While such doubts about independence may or may not be justified, the existence of negative perceptions are relevant in themselves, as was argued in Chapter 2.

It should be noted that the perceptions of the public reflect the appearance of independence, as the vast majority misses the knowledge and information to assess independence by examining the judicial decisions factually. Table 3.2 shows also that the perceptions of the public are highly correlated with those of the lawyers and with the perceptions of the judges. The differences among countries are not in doubt.

Level of education plays an important role in the assessment of independence: on average a high education leads to a more positive perception of independence, and low education to a less positive perception (EC 2019b). See Fig. 3.2. Across countries, the mean score falls from 5.7 for high education (finished education older than 20) to 5.1 for low education (left education younger than 15). The standard deviation for low 


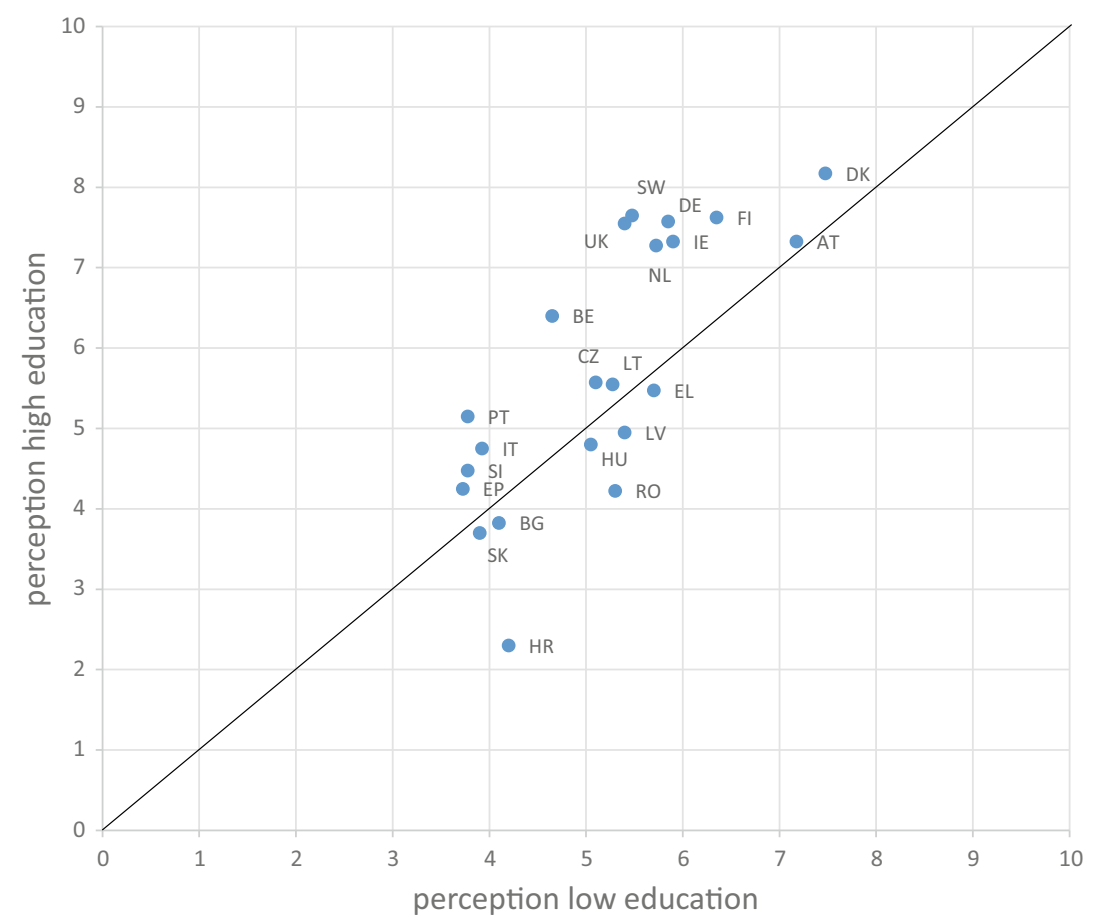

Fig. 3.2 Perceived independence by the general public, by level of education, average per country

education is smaller than that for high education (1.0 vs 1.6), suggesting that the latter persons are more discerning. For judiciaries with a very positive perception of independence by judges and lawyers the effect of different levels of education on the perceptions by the public is much larger than in judiciaries with a less positive perception. The difference is larger, the more positive the perception of independence by for instance lawyers. ${ }^{8}$ If independence is compromised, citizens agree on that, irrespective of their level of education. If independence is strong, respondents

${ }^{8}$ Linear regression at country level: Ind Public High Edu - Ind Public Low Edu $=$ $0.72 * * \times$ Ind Lawyers $-4.04 ; N=17 ; R^{2}=0.65$. Thus, if Ind Lawyers is 10 , the difference between high and low education is 3.2 points, while if Ind Lawyers is 5 , the difference is -0.4 points. 
with a high education recognize this better than respondents with a low education. For example, in Sweden citizens with high education score judicial independence at 7.6, while citizens with low education score at 5.5 , which should be compared with the score by judges of 8.6 and by lawyers of 8.2. When perceptions of judges and lawyers are less positive, the difference is smaller. For instance in Lithuania, the scores are 5.6 and 5.3 , to be compared with 7.7 and 5.9 of judges and lawyers.

In several countries where independence is in relatively low regard by judges and lawyers, the impact of education is reversed. In Romania citizens with high education give a score of 4.2 and with low education 5.3, and in Latvia 4.9 and 5.4. In Hungary, Slovakia and Greece the same effect can be observed, but to a lesser degree. ${ }^{9}$ In all these countries citizens with low education believe that the judiciary is more independent than citizens with a high education. Not surprisingly, the perceptions about judicial independence of highly educated citizens are much more aligned with those of judges and lawyers than citizens with low education. ${ }^{10}$ This may be due to differential exposure to accurate information and/or differing abilities to filter information accurately, but also to a better working of the judicial system for highly educated people. With regard to information persons with low education may be exposed to other media than persons with high education. The differential effect of sensationalist and serious media has been shown for the US (Johnston and Bartels 2010).

A consequence is that citizens with low education in countries that are quite distinct in the eyes of all other groups, may perceive the independence of their respective judiciaries similarly (see Fig. 3.2). This is the case for instance for Latvia and the UK, Romania and Sweden, and Greece and the Netherlands. This could explain why populist parties that draw support from among these groups often rally against judiciaries (see Chapter 7) and find internationally common ground. It is a concern that judiciaries lack connection with these segments of society.

Apart from education, the survey gives some other characteristics of the respondents (EC 2019b). The impact of these is smaller than of

\footnotetext{
${ }^{9}$ For Hungary the scores are respectively 4.8 and 5.1, for Slovakia 3.7 and 3.9 and for Greece 5.5 and 5.7 .

${ }^{10}$ Across 17 countries correlation coefficients are $0.69 * *$ between perceptions by judges (all) and perceptions by citizens with high education, and 0.35 between perceptions of judges and perceptions by citizens with low education. The same correlation coefficients but with regard to the perceptions by lawyers are: $0.83^{* *}$ and 0.38 .
} 
education. As to age, young people are more positive about judicial independence than old people on average across countries. This holds for countries in Eastern Europe, but not for Western European countries. Geographical categories (rural villages, small/mid-size towns and large towns) do not show substantial differences. This is interesting, as populist support is often suggested to be higher outside the big cities.

The outcomes for citizens in Europe can be compared with the results for similar surveys in the US, where citizens (registered voters) are surveyed regularly about the functioning of the state courts. The sample is relatively small: 1,000. The questions do not address independence directly, but some questions are connected. In the survey that was held in November $2019,54 \%$ of the respondents see the state courts as fair and impartial, $49 \%$ as unbiased in their case decisions, but $55 \%$ see state courts as political. This compares broadly with the Eurobarometer survey: 56\% of the respondents perceive independence to be very good or fairly good for the EU28 (EC 2019b, Table Q1).

Can we get deeper into the opinions of the public? A comparison is possible with a one-off Eurobarometer survey commissioned by the European Commission about the rule of law: it focuses on the importance citizens attach to a range of aspects of the rule of law and the need for improvement of these aspects according to them (EU 2019c). Several aspects that the survey examines concern the existential notion of effective judicial protection by independent courts. In this context particularly relevant are the following aspects with the statements put to respondents in brackets: access to an independent court ("if individuals" rights are not respected, they can have them upheld by an independent court)", the independence of judges ("judges are independent and are not under the influence of politicians or economic interests"), respect for and application of court rulings ("public authorities and politicians respect and apply court rulings") and criticism on judges ("codes of conduct for politicians imposing limits on politicians criticizing courts and judges"). On all these four aspects around $50 \%$ of the respondents on average across countries see a definite need for improvement and another 30\% answers "maybe somewhat". While the aspects just mentioned are very interesting, the answers are unfortunately not informative as they are extremely correlated (correlation coefficients 0.98 or 0.99 at country level). Also, the correlation is very high with the percentage of respondents that recognize a definite need to improve timeliness and costs of court procedures $(0.85$ and 0.86$)$. The correlation with the above discussed perceptions of 
the public about independence is -0.74 (correlation between the independence score and the need for improvement of independence). The outcomes of both surveys are consistent in that respect. Apparently, the public has a rough idea of the independence of the courts, but does not distinguish between the aspects put to it. For the public, the aspects mentioned go hand in hand, and no specific aspects jump out. Consequently, it cannot be expected from the general public that it has an opinion about the deeper aspects of independence.

\subsection{Independence as Perceived by Companies}

A Eurobarometer survey is available about the perceptions of independence by companies (EC 2019a). This survey has the same design as the survey among the general public. The outcomes of the two surveys are highly correlated and the mean scores are very close to each other. For the 22 countries sample the mean is 5.6 with a range of 2.5 for Croatia to 8.6 for Denmark. Table 3.2 gives again the outcomes for the two subsets. For the two subsets the means are nearly the same for the public and for firms, and the correlation coefficients are very high.

The statistics hide underlying differences. There are very large "do not know" categories for some countries. Hungary (53\%), Estonia (48\%), Slovenia (30\%), Lithuania (27\%), Portugal (27\%), Sweden $(24 \%)$, and Poland (22\%) have percentages above $20 \%$. These percentages are much higher than those for citizens, for instance in Hungary (citizens 24\%) and in Estonia (citizens 30\%). This uncertainty could be caused by unfamiliarity of companies with the courts, but this is highly unlikely, given the prevalence of legal disputes in economic life that require court intervention (see the next section). If it may be assumed that firms are knowledgeable about the courts, the likely cause would be the political climate in the countries concerned, affecting the current and future independence of the courts in general or with respect to business litigation in particular. This uncertainty is likely to have negative effects on the behaviour of the companies for instance with regard to investment.

The size of companies seems to play a role (EC 2019a, p. 11). The survey is in this respect not more than indicative, as the number of participating large companies is small. The larger the company, the higher it's perception of judicial independence. On average across countries, the independence score of the smallest companies ( $1-9$ employees) is 5.6, and 
that of the largest (more than 250 employees) 7.0. ${ }^{11}$ Differences between countries are erratic probably due to the small number of observations.

\subsection{Independence as Perceived BY THE USERS OF THE COURT}

In this section the focus is on the parties in procedures. To elicit the opinions of these court users, two methods can be used. The first method makes use of a survey among the general population and filters out the respondents that have been to court. This method is used in the US, for instance, for the state courts (GBAO 2020). The Eurobarometer survey about independence among the public has not been designed with this purpose in mind, but distinguishes between citizens with and without experience with the courts by asking whether they have been involved in any dispute which went to court in the last two years (EC 2019b). ${ }^{12}$ Only a small percentage of the public has that experience: across countries the mean is $6.2 \%$ with a range between $2 \%$ in Finland and Sweden and $8 \%$ in Portugal and Slovakia with Croatia as outlier with $12 \%$. The absolute numbers per country are low: between 16 and 124 respondents with a median of 59. Still, it gives an impression. When comparing respondents with and without experience, results must be used with caution, as selection effects may occur. From a methodological point of view, the low number of respondents with recent experience can be resolved by oversampling (see e.g. World Bank 2018). The survey about companies contains the same question about experience as the survey among citizens. $^{13}$ The percentage of companies that have experience is $10.5 \%$ in the mean, with $3 \%$ in the UK and Sweden and $19 \%$ in Germany and Belgium with Croatia again as outlier with $28 \%$. Absolute numbers of respondents with experience are low: between 6 and 75 with a median of 22 .

The other approach to elicit the views of court users is a court user survey. In Europe only a small number of judiciaries are systematically conducting court user surveys, and of those only two include questions

${ }^{11}$ All across countries means of the perceptions by companies and by judges (all) and lawyers differ except for the comparison of lawyers and large firms.

12 Dataset at https://data.europa.eu/euodp/en/data/dataset/S2199_474_ENG/res ource/lfa9ld65-09fl-4011-9ef9-c062cfe1752e.

13 https://data.europa.eu/euodp/nl/data/dataset/S2196_475_ENG/resource/02e 2b962-bfe0-4136-821a-aacc96089395. 
about independence or related concepts such as impartiality (the Netherlands) and neutrality (Denmark). Such a survey is a major investment for courts, as the survey cannot be implemented by the Internet without selection effects. CEPEJ is promoting the use of court user surveys and has had success (CEPEJ 2018). These surveys, however, concern individual courts. To get an indication of the perceptions of court users at present, the Eurobarometer surveys have to be relied on, and the results can only be contrasted with the scant figures from court user surveys.

The question is whether experience has an impact on perceived independence. Effects of experience are likely, as the infrequent contacts of citizens, in particular, with the courts does not easily allow for the development of accurate expectations among the whole population. Also, personal experiences are likely to be varied due to the variety of court cases and their outcomes. Many factors play a role. In the first place, hands-on experience would lead to a better understanding of the workings of the courts and the behaviour of judges. This would lead to respondents being more opinionated than respondents without experience. Assuming largely uniform behaviour of judges within a judiciary, one would also expect more homogeneous replies: in the extreme, $100 \%$ would fall in one of the four categories of positive and negative answers that these surveys use, instead of a 'do not know' category. In the second place, a factor is the experience of going to court as such. For the US state courts it has been found that parties have lower confidence in the courts than people that do not have experience with the courts (Benesh 2006). Benesh argues that going to court is not a positive experience for parties. For them the stakes are high, but they have relinquished control over their situation. This is consistent with her finding that citizens that act as jurors and who have consequently low stakes and high control have more confidence. If such negative experience affects perceptions of independence also negatively, this would lead to parties rating the independence of the court lower than citizens with no experience. A similar finding was made by Wenzel et al. (2003) that suggests that the adversarial nature of the US legal system leaves scars.

In the third place, as discussed in Chapter 2, winning or losing one's case plays a role in the satisfaction of court users with the court, and this may have an impact on their perception of the independence of the court, whether or not justified. If winning or losing is dominant in the minds of the parties to such an extent that it determines their perceptions of independence, perceptions would be sharply divided. In the extreme, $50 \%$ of 
the parties is positive about independence and $50 \%$ negative, when court cases end in a winner and loser. This is, luckily, unrealistic. As discussed, procedural justice plays an important role, and reduces the relevance of winning and losing. Conversely, lack of procedural justice leads to more emphasis on winning and losing. Given varying degrees of procedural justice among judiciaries, this would result in differences in perceived independence among judiciaries.

Turning to the results of the surveys, Table 3.3 gives the summary statistics, while Fig. 3.3 presents the overall results in terms of the five answer categories of the survey, and the results for two judiciaries that display typical patterns. There are large differences between citizens and companies. What they have in common, is that experience leads to a reduction of respondents that have no opinion about judicial independence. With regard to citizens the category 'do not know' declines from 13 to $5 \%$. See Fig. 3.3. For companies it declines from 16 to $5 \%$.

As to the differences, the independence score awarded by citizens with experience is significantly lower than that of inexperienced citizens (5.0 vs $\mathbf{5 . 5}$ for 17 countries). See Table 3.3. This is the case for nearly all countries. Exceptions are few: Finland, Portugal, Slovakia and Romania. A lower score of more than 1 point is found for Germany, Ireland and the Netherlands.

The independence score of companies differs not significantly for firms with experience and without experience. The means, however, disguise big differences among judiciaries. There are countries with positive and with negative differences. Large positive differences due to experience are found for the UK, Czech Republic (more than 2 points), Austria, the Netherlands, Slovenia (between 1 and 2 points). Large negative differences are found for Latvia, Bulgaria, Hungary and Romania (more than 2 points). Thus, experience has a differential effect.

Table 3.3 shows also that perceptions of citizens with experience are less highly correlated with the perceptions of judges and lawyers than perceptions of citizens with no experience. This would be in line with the individualized experience of court users in which winning or losing plays a role. This effect is not observed for companies that seem to be more rational.

Perceptions tend to get more extreme. See Fig. 3.3. There is a tendency towards the extremes (very good; very bad) with experience in countries, where this is possible (in Denmark this is, for instance, not the case, as the upward effect of winning is truncated by the ceiling), 
All countries: citizens

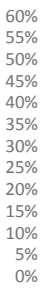

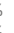

very good fairly good don't know fairly bad verybad

No experience Experience

22 countries score no experience score experience

$\%$ experience

\# with experience

$\%$ extreme no exp

$\%$ extreme exp

$\%$ homogeneous no exp

$\%$ homogeneous exp

Italy: citizens

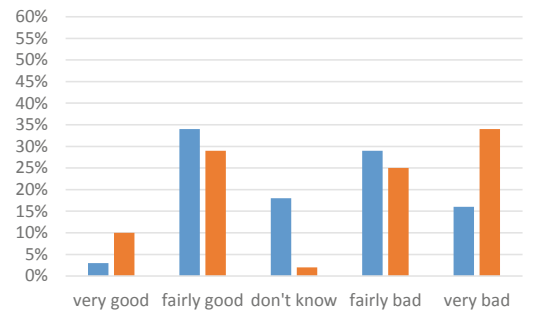

very good fairly good don't know fairly bad very bad

no experience experience

Italy
score no experience
score experience
$\%$ experience
\# with experience
$\%$ extreme no exp
$\%$ extreme exp
$\%$ homogeneous no exp
$\%$ homogeneous exp

All countries: companies

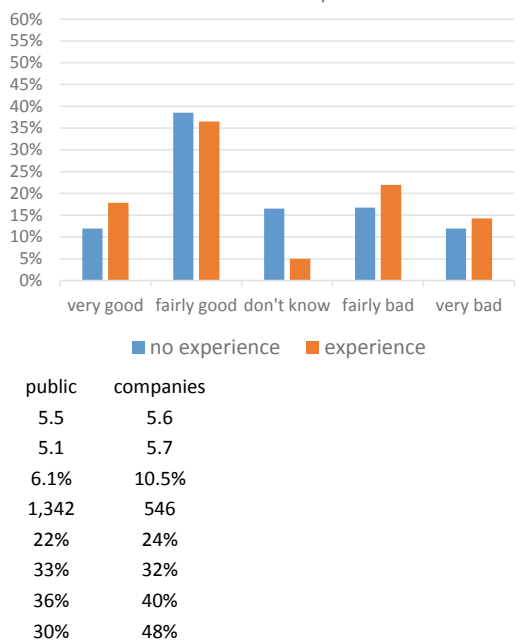

Italy: companies

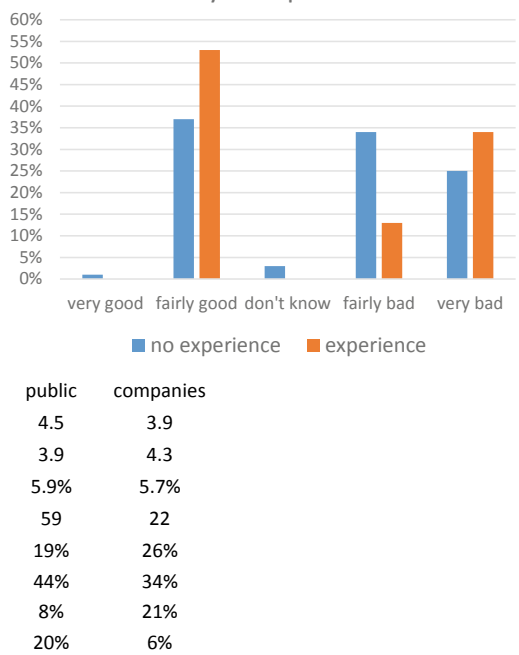

Fig. 3.3 Score of judicial independence by the public and by companies, without and with experience with disputes in court, average for 22 countries and average scores for Italy and for Czechia (Notes [1] Experience: involvement in any dispute which went to court in the last two years; [2] Extreme: sum of answer categories 'very good' and 'very bad', for respondents with and without experience; [3] Homogeneous: absolute value of '(very) good' minus '(very) bad', for respondents with and without experience) 


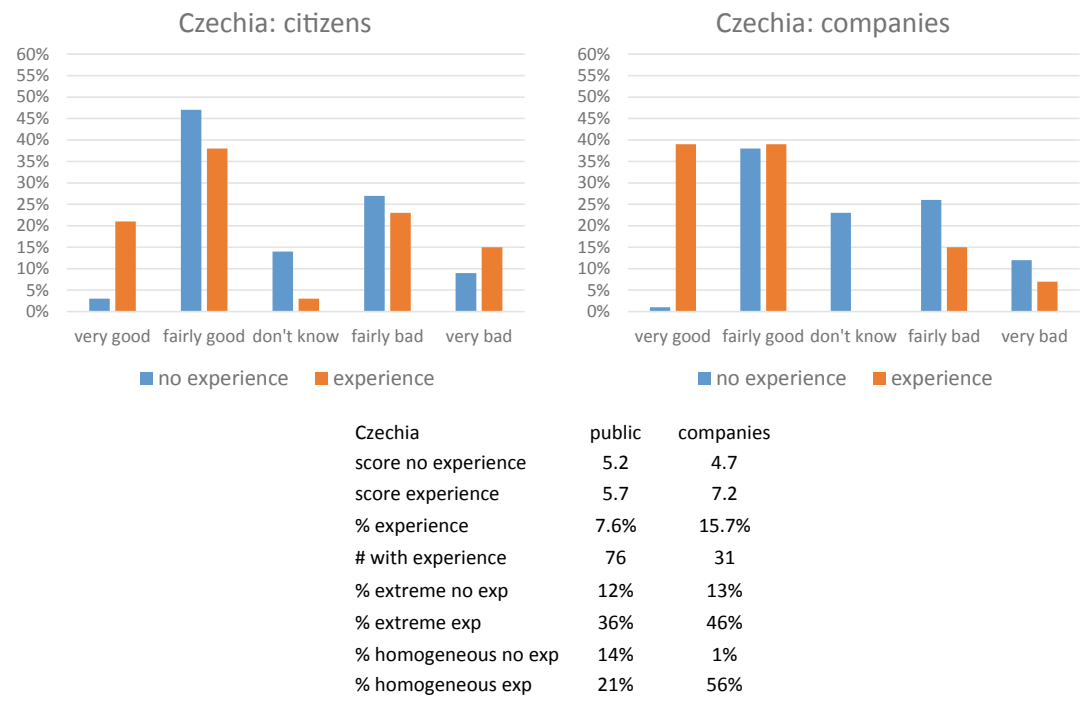

Fig. 3.3 (continued)

that can be attributed to the impact of winning and losing cases. "Very good" increases from 10 to $13 \%$ of citizens and from 12 to $18 \%$ of companies. "Very bad" increases from 11 to $20 \%$ for citizens and 12 to $14 \%$ of companies. In 14 out of 22 countries very good is higher for citizens with experience, and in 20 countries very bad is higher. Winning and losing seems to play a role for citizens in most countries. The impact on the perceptions of companies is more differentiated among countries.

The perceptions of citizens are less homogeneous for experienced than for inexperienced citizens, when measured as the percentages of very good and fairly good minus very bad and fairly bad. The absolute value of these differences across countries gives an indication whether respondents agree that the judiciary is independent or not independent. For citizens this percentage is lower for experience than for no experience (28 vs $35 \%$ ). For companies, it is the other way round ( 48 vs $40 \%$ ).

While the data allow only tentative conclusions, the main finding is that winning and losing has the most consistent effect, together with the reduction of uncertainty as such.

As mentioned before, the use of court user surveys that include questions concerning the independence or impartiality of judges is very limited 
in the countries examined here. This is telling about the mentality of the courts. Denmark and the Netherlands are conducting such surveys on a regular basis, the last one was in Denmark in 2013 (Oxford Research 2013) and in the Netherlands in 2017 (SAMR 2017). In Denmark the item of the survey that touches on independence is neutrality of the judge, and in the Netherlands impartiality of the judge. The survey method is totally different from the Eurobarometer, as the survey is administered in the courts. In Denmark $84 \%$ of the respondents replied that judges are neutral, 10\% was indifferent or did not know and 6\% answered that judges are not neutral. These outcomes compare with the results of the Eurobarometer for respondents with experience: $77 \%, 7 \%$ and $16 \%(n=$ $36)$, and without experience: $88 \%, 7 \%$ and $5 \%(n=966)$.

For the Netherlands, in the court user survey $79 \%$ of the respondents answered that the judge was impartial, 16\% was neutral or did not know and $5 \%$ responded that the judge was not impartial. The Eurobarometer collected much more critical responses: with experience $60 \%, 8 \%$, and $32 \%$ $(n=70)$, and without experience $73 \%, 14 \%$ and $13 \%(n=927)$. While differences are to be expected in view of the different questions and the different methodology, the outcomes are roughly consistent for Denmark but not for the Netherlands. More court user surveys are needed to enable a comparison of the two research methods. In addition court user surveys offer the possibility to differentiate the court users with respect to social and cultural background. Given the inequalities in society, this differentiation is particularly important (see e.g. Wenzel et al. 2003 on the US).

\subsection{EXPLANATIONS of the Differences of Perceptions}

The main conclusion is that the perceptions among categories of actors, with the exception of the general public with low education, are highly correlated. At the same time perceptions differ substantially in level with judges generally being more positive about their independence than lawyers, and lawyers being more positive than the public in general, and in particular citizens with low education, as well as companies, and in particular small companies.

The impact of education is unexpected: the difference of the independence scores of citizens with high education and the scores of citizens with low education is positive and large in countries with a high level 
of independence according to judges and lawyers. When independence is perceived to be low, the differences disappear, and in some countries are even reversed. Citizens with low education are more positive about independence than citizens with high education.

As to the parties in law suits, the availability of data is an impediment. Also, the interaction of gaining more insight by personal experience in the independence of judges and the potential impact of winning and losing cases complicates the analysis. The data clearly indicate that people with experience are more opinionated about independence (much less 'do not know' answers are given), and also that opinions of persons with experience are more extreme than the opinions of those without experience, suggesting that winning and losing play a role. It was also found that the main score of independence for citizens with experience is lower than that for citizens without experience. This leads to an even larger distance to the perceptions of judges than the inexperienced public has. It must be noted that selection effects (for instance for citizens with respect to education and for companies firm size) may play a role, but this cannot be checked because of the data limitations.

What could explain the lack of alignment of judges and society? Two extreme explanations will be considered in the next chapters.

(1) Judges live in the often suggested ivory tower:

- Judges evaluate their independence too positively, consciously or unconsciously. They have a strong esprit de corps, are not open for criticism, and in denial about the workings of the legal system. They are focussed on their case work, and do not pay attention to the big picture.

- Lawyers are more critical than judges, but they are part of the judicial/legal system, benefit from it, and are therefore more positive than external observers would be.

- The perceptions of the court users and the general public may be biased, but, just because they are outsiders, their perceptions are more reliable and informative than those of judges and lawyers.

(2) The general public is not well informed about the courts, and biased negatively due to influence of media, social media and in some countries politics: 
- Judges are accurate about judicial independence in general in their country, and their perceptions are reliable and informative.

- The perceptions of lawyers are affected by winning and, in particular, losing cases. Also, they are dependent on the judges, and lack control over the proceedings which as such is frustrating.

- Parties are affected by winning and losing, as was shown above, and more intensely so than lawyers. They also lack control to a larger degree than the lawyers, and they cannot recognize when justice is done.

- The general public is subject to (social) media influence. The media report selectively with an emphasis on sensational events and matters that have gone wrong. Negative events have a stronger and more lasting impact than positive events (Baumeister et al. 2001).

- Distrust of public institutions in general affects the perception of judicial independence by the public.

The next Chapter examines how citizens who take part in the judiciary as lay judges view the independence of the judiciary. In as far as lay judges are critical observers of the judicial system, their perceptions about judicial independence could be decisive in determining which of these two extreme explanations is most valid.

\section{Abbreviations of Countries}

$\begin{array}{ll}\text { AT } & \text { Austria } \\ \text { BE } & \text { Belgium } \\ \text { BU } & \text { Bulgaria } \\ \text { CZ } & \text { Czechia } \\ \text { DK } & \text { Denmark } \\ \text { EL } & \text { Greece } \\ \text { EE } & \text { Estonia } \\ \text { ES } & \text { Spain } \\ \text { FI } & \text { Finland } \\ \text { DE } & \text { Germany } \\ \text { HR } & \text { Croatia } \\ \text { IE } & \text { Ireland }\end{array}$




$\begin{array}{ll}\text { IT } & \text { Italy } \\ \text { LV } & \text { Latvia } \\ \text { LT } & \text { Lithuania } \\ \text { HU } & \text { Hungary } \\ \text { NL } & \text { The Netherlands } \\ \text { PL } & \text { Poland } \\ \text { PT } & \text { Portugal } \\ \text { RO } & \text { Romania } \\ \text { SI } & \text { Slovenia } \\ \text { SK } & \text { Slovakia } \\ \text { SW } & \text { Sweden } \\ \text { UK } & \text { United Kingdom } \\ \text { EW } & \text { England and Wales } \\ \text { SC } & \text { Scotland }\end{array}$

\section{REFERENCES}

Baumeister, R.F., E. Bratslavsky, C. Finkenauer, and K.D. Vohs. 2001. Bad is stronger than good. Review of General Psychology 5 (4): 323-370.

Benesh, S.C. 2006. Understanding public confidence in American courts. Journal of Politics 68 (3): 697-707.

Buunk, B.P., and N.W. van Yperen. 1991. Referential comparisons, relational comparisons, and exchange orientation: their relation to marital satisfaction. Personality and Social Psychology Bulletin 17 (6): 709-717.

CEPEJ. 2018. European judicial systems: Efficiency and quality. CEPEJ Studies No 23.

ENCJ. 2018. Data ENCJ Survey on the independence of lay judges 2017-2018. encj.eu.

ENCJ. 2019. Independence and accountability of the judiciary: ENCJ Survey on the independence of judges 2019. encj.eu.

ENCJ and CCBE. 2019. Independence and accountability of the judiciary: ENCJ/CCBE Survey among lawyers on the independence of judges 2019. encj.eu.

European Commission. 2019a. Perceived independence of the national justice systems in the EU among companies. Flash Eurobarometer 475.

European Commission. 2019b. Perceived independence of the national justice systems in the EU among the general public. Flash Eurobarometer 474.

European Commission. 2019c. Rule of law. Special Eurobarometer 489.

GBAO. 2020. State of the State Courts, Survey analysis. 
Giladi, E.E., and Y. Klar. 2002. When standards are wide of the mark: Nonselective superiority and inferiority biases in comparative judgments of objects and concepts. Journal of Experimental Psychology 131 (4): 538-551.

Johnston, C.D., and B.L. Bartels. 2010. Sensationalism and sobriety: Differential media exposure and attitudes toward American courts. Public Opinion Quarterly 74 (2): 260-285.

Landes, W.M. 1971. An economic analysis of the courts. Journal of Law and Economics 14 (1): 61-107.

Oxford Research. 2013. Brugerundersøgelse af Danmarks domstole 2013, udarbejdet for domstolsstyrelsen, bilag.

Posner, R.A. 1973. An economic approach to legal procedure and judicial adminis-tration. The Journal of Legal Studies 2 (2): 399-458.

SAMR. 2017. Klantwaardering Rechtspraak 2017; Landelijk rapport. https:// www.rechtspraak.nl/SiteCollectionDocuments/landelijke-rapportage-KWO2017.pdf\#search=klantwaarderingsonderzoek $\% 202017$.

Svenson, O. 1981. Are we all less risky and more skilful than our fellow drivers? Acta Psychologica 47 (2): 143-148.

Wenzel, J.P., S. Bowler, and D.J. Lanoue. 2003. The sources of public confidence in state courts; experience and institutions. American Political Research 31 (2): 191-211.

World Bank. 2018. Montenegro-Experiences and perceptions of Judiciary's performance (c) World Bank.

Open Access This chapter is licensed under the terms of the Creative Commons Attribution 4.0 International License (http://creativecommons.org/licenses/ by $/ 4.0 /$ ), which permits use, sharing, adaptation, distribution and reproduction in any medium or format, as long as you give appropriate credit to the original author(s) and the source, provide a link to the Creative Commons license and indicate if changes were made.

The images or other third party material in this chapter are included in the chapter's Creative Commons license, unless indicated otherwise in a credit line to the material. If material is not included in the chapter's Creative Commons license and your intended use is not permitted by statutory regulation or exceeds the permitted use, you will need to obtain permission directly from the copyright holder.

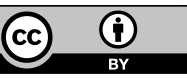

